Effect of al umi num on met abol i sm of or gani $c$ aci ds and chemical for ms of al um num in root t i ps of Eucal ypt us camal dul ensi s Dehnh

\begin{tabular}{|l|l|}
\hline 著者 & $\begin{array}{l}\text { I kka Takashi, Ogawa Tsuyoshi, Li Donghua, } \\
\text { H r adate Syunt ar o, Mori ta Aki o }\end{array}$ \\
\hline $\begin{array}{l}\text { j our nal or } \\
\text { publ i cat i on ti t l e }\end{array}$ & Phyt ochemi st ry \\
\hline vol une & 94 \\
\hline page range & $142-147$ \\
\hline year & $2013-10$ \\
\hline 出版者 & El sevi er \\
\hline 権利 & $\begin{array}{l}\text { Copyr i ght (C) 2013 El sevi er Lt d. Al I ri ght s } \\
\text { reser ved. }\end{array}$ \\
\hline URL & ht t p: //hdl . handl e. net /10297/7408 \\
\hline
\end{tabular}




\title{
Effect of aluminum on metabolism of organic acids and chemical forms of aluminum in root tips of
} Eucalyptus camaldulensis Dehnh.

\author{
Takashi Ikka ${ }^{\mathrm{a}}$, Tsuyoshi Ogawa ${ }^{\mathrm{a}}$, Donghua $\mathrm{Li}^{\mathrm{a}}$, Syuntaro Hiradate ${ }^{\mathrm{b}}$, Akio Morita $^{\mathrm{a}}$ \\ ${ }^{a}$ Graduate School of Agriculture, Shizuoka University, 836 Ohya, Suruga-ku, Shizuoka 422-8529, Japan \\ ${ }^{\mathrm{b}}$ National Institute of Agro-Environmental Sciences, 3-1-3 Kan-nondai, Tsukuba, Ibaraki 305-8604, Japan
}

\begin{abstract}
Eucalyptus (Eucalyptus camaldulensis) has relatively high resistance to aluminum (Al) toxicity than the various herbaceous plants and model plant species. To investigate Al-tolerance mechanism, the metabolism of organic acids and the chemical forms of $\mathrm{Al}$ in the target site (root tips) in Eucalyptus was investigated. To do this, 2-year old rooted cuttings of E. camaldulensis were cultivated in half-strength Hoagland solution ( $\mathrm{pH} 4.0)$ containing $\mathrm{Al}(0,0.25,0.5,1.0,2.5$ and $5.0 \mathrm{mM})$ salts for 5 weeks; growth was not affected at concentrations up to $2.5 \mathrm{mM}$ even with $\mathrm{Al}$ concentration reaching $6000 \mu \mathrm{g} \mathrm{g}{ }^{-1} \mathrm{DW}$. In roots, the citrate content also increased with increasing Al application. Concurrently, the activities of aconitase and $\mathrm{NADP}^{+}$-isocitrate dehydrogenase, which catalyze the decomposition of citrate, decreased. On the other hand, the activity of citrate synthase was not affected at concentrations up to $2.5 \mathrm{mM} \mathrm{Al}$. ${ }^{27} \mathrm{Al}-\mathrm{NMR}$ spectroscopic analyses were carried out where it was found that Al-citrate complexes were a major chemical form present in cell sap of root tips. These findings suggested that E. camaldulensis detoxifies Al by forming Al-citrate complexes, and that this is achieved through Al-induced citrate accumulation in root tips via suppression of the citrate decomposition pathway.
\end{abstract}

\section{Keywords}

Eucalyptus; Eucalyptus camaldulensis; Myctaceae; Aluminum tolerance; Organic acid metabolism; ${ }^{27}$ Al-NMR analysis; Al-citrate complex

\section{Introduction}

In acidic soils, which account for approximately $40 \%$ of the earth's arable land, $\mathrm{Al}^{3+}$ toxicity is a major factor limiting plant productivity (Taylor, 1991). The root growth of many agriculturally important crops, including wheat (Triticum aestivum) and maize (Zea mays), are suppressed by low (micromolar) levels of $\mathrm{Al}^{3+}$ within minutes or hours (Matsumoto, 2000). Therefore, it is important to understand the $\mathrm{Al}^{3+}$-tolerance mechanisms of plants to establish strategies to increase crop productivity in acidic soils.

Many studies have examined $\mathrm{Al}^{3+}$-tolerance mechanisms by using either tolerant cultivars or lines of Al-sensitive plant species. Until now, it was thought that $\mathrm{Al}^{3+}$ exclusion from the root apex, the so-called external detoxification mechanism, was the most important mechanism for $\mathrm{Al}^{3+}$ tolerance in these plant 
species. In this process, plants can exclude $\mathrm{Al}^{3+}$ by actively transporting it out of the cytoplasm (Taylor, 1991 and Kochian, 1995), and when the concentration of $\mathrm{Al}^{3+}$ in the rhizosphere is reduced by the increase in root surface pH (Degenhardt et al. 1998) and by Al-chelating substances secreted from the roots (i.e. Kitagawa et al. 1986). Many plant species secrete low molecular weight organic acids as chelators from roots in response to $\mathrm{Al}^{3+}$. For example, malate was released from the roots of $\mathrm{Al}^{3+}$-tolerant cultivars of wheat (Delhaize et al. 1993), and citrate from $\mathrm{Al}^{3+}$-tolerant cultivars of maize (Pellet et al. 1995). $\mathrm{Al}^{3+}$-tolerant oat (Avena sativa) (Zheng et al. 1998) and rye (Secale cereale) (Li et al. 2000) also released both malate and citrate in response to $\mathrm{Al}^{3+}$. Recently, genetic approaches showed that malate and citrate exudation were controlled by transporters, including an $\mathrm{Al}^{3+}$-activated malate transporter (ALMT1) in wheat (Sasaki et al. 2004) and a multi-drug and toxic compound extrusion (MATE) process in sorghum (Magalhaes et al. 2007). Moreover, $\mathrm{Al}^{3+}$ treatments stimulated citrate synthesis in some plant species via increased citrate synthase (CS) activity and/or decreased isocitrate dehydrogenase (ICDH) activity in the tricarboxylic acid (TCA) cycle ( Ryan and Delhaize, 2001 and Neumann and Martinoia, 2002).

Some plant species accumulate $\mathrm{Al}^{3+}$ at high concentrations in aerial parts without showing $\mathrm{Al}^{3+}$ toxicity. There is evidence that Al-tolerant plant species have not only external but also internal $\mathrm{Al}^{3+}$-detoxification mechanisms, including chelation by organic acids. For example, the $\mathrm{Al}^{3+}$-tolerant plant buckwheat (Fagopyrum esculentum Moench. cv. Jianxi) secretes oxalate from the roots in response to $\mathrm{Al}^{3+}$ (Ma et al. 1997a). Determination of chemical forms of $\mathrm{Al}^{3+}$ in buckwheat by ${ }^{27} \mathrm{Al}$-nuclear magnetic resonance $\left({ }^{27} \mathrm{Al}-\mathrm{NMR}\right)$ suggested that after $\mathrm{Al}^{3+}$ uptake, it was internally detoxified by formation of $\mathrm{Al}^{3+}$-oxalate complexes in the roots (Ma et al. 1998), $\mathrm{Al}^{3+}$-citrate complexes in the xylem sap, and $\mathrm{Al}^{3+}$-oxalate complexes in the leaves (Ma and Hiradate, 2000), respectively. In the case of tea (Camellia sinensis L.), its growth was stimulated by $\mathrm{Al}^{3+}$ (Konishi et al. 1985), with $\mathrm{Al}^{3+}$ accumulating to more than $30,000 \mathrm{mg} \mathrm{kg}^{-1}$ in the leaves (Matsumoto et al. 1976). Tea also secreted oxalate from the roots in response to $\mathrm{Al}^{3+}$ (Morita et al. 2011), and $\mathrm{Al}^{3+}$ was also internally detoxified by the formation of $\mathrm{Al}^{3+}$-oxalate complexes in roots (Morita et al. 2008) and $\mathrm{Al}^{3+}$-citrate complexes in the xylem sap (Morita et al. 2004). Tea plants can also store $\mathrm{Al}^{3+}$ as $\mathrm{Al}^{3+}$-catechin complexes in mature leaves (Nagata et al. 1992). As mentioned above, low molecular weight organic acids play a key role in $\mathrm{Al}^{3+}$ detoxification by forming $\mathrm{Al}^{3+}$-organic acid complexes in the cytosol or at the root-soil interface.

Eucalyptus is grown worldwide as an ornamental tree and as a material for the paper industry. Previous reports have shown that Eucalyptus gummifera was able to use insoluble phosphate (aluminum phosphate and iron (III) phosphate) in acidic conditions (Mullette, 1973) and that its growth was stimulated in the presence of $\mathrm{Al}^{3+}$ (Mullette et al. 1974). Symonds et al. (2001) reported that Eucalyptus generally showed a higher growth rate under acidic conditions (pH 5.1-5.6) in all 35 species examined. Moreover, Eucalyptus camaldulensis, one of the most popular and valuable species in the genus Eucalyptus, can grow in acid soils (Osaki et al. 1998), i.e. where the soil $\mathrm{pH}$ is lower than 3.5 and the $\mathrm{Al}^{3+}$ concentration in the soil solution reaches the millimolar level (van Breemen and Pons, 1978). Indeed, in studies using these species under hydroponics ( Osaki et al., 1997, Nguyen et al., 2003a and Tahara et al., 2005), E. camaldulensis was highly resistance to $\mathrm{Al}^{3+}$ than some of the crops mentioned above, and root elongation of this plant was not 
inhibited even by $1 \mathrm{mM} \mathrm{Al}^{3+}$ for 20 days (Tahara et al. 2005). In addition, Nguyen et al. (2003a) and Tahara et al. (2008) suggested that E. camaldulensis showed increased citrate content in the roots in response to $\mathrm{Al}^{3+}$. That study also reported that the secretion of citrate and oxalate from roots of E. camaldulensis increased in response to $\mathrm{Al}^{3+}$ (Nguyen et al., 2003b). These findings thus suggested that Eucalyptus has internal and external $\mathrm{Al}^{3+}$-tolerance mechanisms based on chelation of $\mathrm{Al}^{3+}$ with organic acids, like buckwheat and tea. However, little is known about $\mathrm{Al}^{3+}$-induced metabolic changes associated with the synthesis or degradation of organic acids and the chemical forms of $\mathrm{Al}^{3+}$ in Eucalyptus roots.

In this study, in order to clarify $\mathrm{Al}^{3+}$-tolerance mechanisms of Eucalyptus, hydroponically grown $E$. camaldulensis was treated with $\mathrm{Al}^{3+}$ solutions ( $\mathrm{pH}$ 4.0) for 5 weeks. To do this, the contents of $\mathrm{Al}^{3+}$ and low-molecular weight organic acids, the activities of enzymes in the TCA cycle, and the chemical forms of $\mathrm{Al}^{3+}$ in the roots were determined.

\section{Results}

E. camaldulensis grew normally in $\mathrm{Al}^{3+}$ treatments up to $2.5 \mathrm{mM} \mathrm{Al}^{3+}$. Plants in those treatments showed similar fresh weights to that of the control $\left(0 \mathrm{mM} \mathrm{Al}^{3+}\right)$ (Fig. 1). The growth of all plant parts was markedly decreased, however in the $5 \mathrm{mM} \mathrm{Al}^{3+}$ treatment, and the mean total fresh weight was approximately $60 \%$ of that of the control. Symptoms of $\mathrm{Al}^{3+}$ toxicity (leaf chlorosis or necrosis) were not visible in any treatment (data not shown).

$\mathrm{The}^{3 l^{3+}}$ contents in roots and leaves are shown in Fig. 2. In young roots, the $\mathrm{Al}^{3+}$ content increased up to $2.5 \mathrm{mM} \mathrm{Al}^{3+}$, reaching approximately $6000 \mu \mathrm{g} \mathrm{g}^{-1} \mathrm{DW}$ in the 2.5 and $5 \mathrm{mM} \mathrm{Al}^{3+}$ treatments. In young and mature leaves, $\mathrm{Al}^{3+}$ contents also increased with higher levels of $\mathrm{Al}^{3+}$ treatments, and showed the highest values in the $5.0 \mathrm{mM} \mathrm{Al}^{3+}$ treatment. However, the $\mathrm{Al}^{3+}$ concentrations in leaves were much lower than those in young roots. In the $5.0 \mathrm{mM} \mathrm{Al}^{3+}$ treatment, approximately $4 \mu \mathrm{g} \mathrm{Al} \mathrm{g}^{-1} \mathrm{DW}$ accumulated in young leaves and $150 \mu \mathrm{g} \mathrm{Al} \mathrm{g}^{-1} \mathrm{DW}$ accumulated in mature leaves. These findings suggested that $\mathrm{Al}^{3+}$ mainly accumulated in roots of E. camaldulensis.

The contents of organic acids in young roots are shown in Fig. 3. The highest malate content $(0.55 \mu \mathrm{mol}$ $\mathrm{g}^{-1} \mathrm{FW}$ ) was in roots of plants in the $1.0 \mathrm{mM} \mathrm{Al}{ }^{3+}$ treatment, but it did not respond to $\mathrm{Al}^{3+}$ supply. The citrate content increased with increasing $\mathrm{Al}^{3+}$ supply (citrate concentration of $0.79 \mu \mathrm{mol} \mathrm{g}{ }^{-1} \mathrm{FW}$ in the 2.5 $\mathrm{mM} \mathrm{Al}$ treatment) and remained at a higher level in the $5 \mathrm{mM} \mathrm{Al}^{3+}$ treatment. Oxalate contents were more than 10-fold greater than those of malate and citrate, but this did not change in response to $\mathrm{Al}^{3+}$. The oxalate content was approximately $14 \mu \mathrm{mol} \mathrm{g}{ }^{-1} \mathrm{FW}$ in the roots of all plants, regardless of $\mathrm{Al}^{3+}$ treatment.

The activities of phosphoenolpyruvate carboxylase (PEPC) and malate dehydrogenase (MDH), which catalyze the synthesis of malic acid, are shown in Fig. 4. The activity of PEPC was unchanged in treatments up to $2.5 \mathrm{mM} \mathrm{Al}^{3+}$ and then significantly decreased in the $5.0 \mathrm{mM} \mathrm{Al}^{3+}$ treatment. $\mathrm{MDH}$ activity gradually decreased with increasing levels of $\mathrm{Al}^{3+}$ in the treatments. By contrast, the activity of $\mathrm{CS}$, which catalyzes citric acid synthesis, showed an increasing trend with higher levels of $\mathrm{Al}^{3+}$ application, but the increase was not statistically significant (Fig. 5). The activities of aconitase (ACO) and NADP ${ }^{+}$-ICDH, which catalyze 
the decomposition of citric acid, were lower in all of the $\mathrm{Al}^{3+}$ treatments than in the control.

Table 1 shows the contents of $\mathrm{Al}^{3+}$ and organic acids in cell sap extracted from Eucalyptus roots. The cell sap from root tips treated with $1.0 \mathrm{mM} \mathrm{Al}^{3+}$ was strongly acidic $(\mathrm{pH} 4.32)$ and contained $1.03 \mathrm{mM} \mathrm{Al}^{3+}$. The contents of citrate $(1.3 \mathrm{mM})$ and oxalate $(1.49 \mathrm{mM})$ were similar to that of $\mathrm{Al}^{3+}$, but higher than that of malate $(0.26 \mathrm{mM})$. The ${ }^{27} \mathrm{Al}$-NMR spectrum of the cell sap and Al-model solutions are shown in Fig. 6 . In the spectrum of the cell sap, four signals were detected: a large, broad resonance at $11.3 \mathrm{ppm}$, two smaller broad signals at -1.4 and $3.8 \mathrm{ppm}$, and a small, sharp resonance at $15.9 \mathrm{ppm}$. In the spectrum of $\mathrm{Al}$ model solutions, broad peaks at 4.6 and $12.2 \mathrm{ppm}$ were detected in the Al-malate (1:1) solution, and at 1.1 and $10.9 \mathrm{ppm}$ in the Al-citrate (1:1) solution. Sharp peaks were detected at 1.4, 6.6, and $11.7 \mathrm{ppm}$ in the $\mathrm{Al}^{3+}$-oxalate (1:1) solution.

\section{Discussion}

E. camaldulensis was grown in half-strength Hoagland solution ( $\mathrm{pH}^{4.0}$ ) containing various concentrations of $\mathrm{Al}^{3+}(0-5.0 \mathrm{mM})$ for 5 weeks. The growth of E. camaldulensis was not affected by $\mathrm{Al}^{3+}$ up to $2.5 \mathrm{mM}$ (Fig. 1). The $\mathrm{Al}^{3+}$ content in roots of plants in the $2.5 \mathrm{mM} \mathrm{Al}^{3+}$ treatment was approximately $6,000 \mathrm{mg} \mathrm{g}^{-1} \mathrm{DW}$ (Fig. 2). These findings reconfirmed that E. camaldulensis was tolerant to $\mathrm{Al}^{3+}$, as reported by Nguyen et al. (2003a).

The citrate content in the root increased with increasing $\mathrm{Al}^{3+}$ concentrations in the $\mathrm{Al}^{3+}$ treatments (Fig. 5). This was consistent with the results of Nguyen et al. (2003b) and Tahara et al. (2008), and suggested that $\mathrm{Al}^{3+}$ induced citrate accumulation in the roots of E. camaldulensis. Silva et al. (2004) reported that in seedlings of six species of Eucalyptus, E. globulus Labill., E. urophylla S.T. Blake, E. dunnii Maiden, E. saligna Sm., E. cloeziana F.J. Muell and E. grandis w. Hill ex Maiden, root exposure to $\mathrm{Al}^{3+}$ resulted in more than a $200 \%$ increase in malic acid concentration in the root tips, as well as a small increase in citric acid concentration. It was thus concluded that the $\mathrm{Al}^{3+}$ tolerance of these Eucalyptus species was mainly due to internal detoxification of $\mathrm{Al}^{3+}$ by complexation with malic acid. However, the content of malate in the roots of E. camaldulensis did not increase, or only slightly increased, with increasing $\mathrm{Al}^{3+}$ supply. These findings suggested that different Eucalyptus species might accumulate different types of organic acids in their roots in response to $\mathrm{Al}^{3+}$.

Generally, citrate accumulates in higher plants via suppression of citrate decomposition in the cytosol, since the activity of $\mathrm{CS}$ in mitochondria is not stimulated by $\mathrm{Al}^{3+}$ (Neumann and Martinoia, 2002). Meanwhile, the $\mathrm{Al}^{3+}$-tolerant carrot suspension culture cell line selected by Koyama et al. (1988) secreted citrate. In these cells, there was an increase in CS mRNA transcripts (Takita et al. 1999) and a decrease in ICDH mRNA transcripts (Kihara et al. 2003a). CS activity increased in response to the $\mathrm{Al}^{3+}$ has been reported in various plant species such as soybean (Yang et al. 2001), common bean (Mugai et al. 2000) and Cassia tora L. (Yang et al. 2004). These results suggested that $\mathrm{Al}^{3+}$ regulates CS activity and citrate accumulation in roots. On the other hand, accumulation of citrate in the cytosol is achieved by reduced activity of the ACO and NADP-ICDH that are involved in citrate turnover (Massonneau et al., 2001, Anoop 
et al., 2003 and Rangel et al., 2010). In white lupin, which showed high citrate exudation activity, the citrate metabolic system (activities of ICDH and ACO) in the cytosol was blocked under phosphate deficiency (Kania et al., 2003 and Kihara et al., 2003b). In lemon, ACO activity was suppressed at the transcriptional level at the stage when citrate accumulated in the fruit (Sadka et al. 2000). In this study, the activities of $\mathrm{ACO}$ and $\mathrm{NADP}^{+}-\mathrm{ICDH}$ in E. camaldulensis roots decreased in the $\mathrm{Al}^{3+}$ treatments, while CS activity remained unchanged up to the $2.5 \mathrm{mM} \mathrm{Al}^{3+}$ treatment (Fig. 6). Therefore, in roots of $E$. camaldulensis, $\mathrm{Al}^{3+}$ resulted in suppressed citrate decomposition via the reduction of ACO and $\mathrm{NADP}^{+}$-ICDH activities, resulting in increased citrate content.

In the ${ }^{27} \mathrm{Al}-\mathrm{NMR}$ spectrum of the cell sap from root tips treated with $1.0 \mathrm{mM} \mathrm{Al}{ }^{3+}$, there were four signals: at $1.4,3.8,11.3$, and $15.9 \mathrm{ppm}$. A resonance at around $0 \mathrm{ppm}$ suggests the presence of $\mathrm{Al}^{3+}$ monomeric species (Kerven et al. 1995) and another around $3 \mathrm{ppm}$ indicates $\mathrm{Al}^{3+}$ bound to a carboxyl group of an organic acid, such as malic acid (Hiradate, 2004). Therefore, the two signals at -1.4 and 3.8 ppm suggested the presence of $\mathrm{Al}^{3+}$ monomeric species and $\mathrm{Al}^{3+}$ binding to malic acid, respectively. Two resonances were detected at around $11.3 \mathrm{ppm}$ : one large broad signal at 10.9-12.9 ppm in the Al-citrate solution and another sharper resonance at $11.7 \mathrm{ppm}$ in the Al-oxalate solution. In addition, the peak pattern when the Al-oxalate complexes was observed as a main peak at $6.6 \mathrm{ppm}$, the concentration of oxalate in the cell sap appears to be lower than ratio of the peak area at $11.7 \mathrm{ppm}$ (Table 1). Therefore, the large broad signal at $11.3 \mathrm{ppm}$ in the cell sap indicated the presence of Al-citrate complexes in the roots of $E$. camaldulensis. In a previous report (Morita et al. 2008), it was demonstrated showed that the peak at 16.1 $\mathrm{ppm}$ in the tea cell sap at $\mathrm{pH} 5.0$ was due to $\mathrm{Al}^{3+}$-oxalate $(1: 3)$ complex, although the $\mathrm{pH}$ value in eucalyptus cell sap solutions was 4.3 in this study. Consequently, the resonance at $15.9 \mathrm{ppm}$ in cell sap did not derive from the $\mathrm{Al}^{3+}$-oxalate (1:3) complex. Tahara et al. (2008) reported that the unknown low-molecular-weight (LMW) $\mathrm{Al}^{3+}$-binding ligand contributes to $\mathrm{Al}^{3+}$ resistance in E. camaldulensis. It is thus possible that the spectrum of the cell sap might represent not only the A1-citrate complex but also the unknown Al-LMW complex.

\section{Conclusions}

In conclusion, the results of this study demonstrate that the roots of E. camaldulensis display internal tolerance to $\mathrm{Al}^{3+}$ by forming $\mathrm{Al}^{3+}$-citrate complexes through increasing citrate contents and suppressing citrate decomposition. These mechanisms resulted in accumulation of $\mathrm{Al}^{3+}$ up to $6000 \mu \mathrm{g} \mathrm{g}^{-1} \mathrm{DW}$ in the roots.

\section{Experimental}

\subsection{Plant materials and treatment conditions}

Rooted cuttings of E. camaldulensis (2-years old) were transferred into Wagner pots containing $12 \mathrm{~L}$ tap $\mathrm{H}_{2} \mathrm{O}$ adjusted to $\mathrm{pH} 6.0$ with either $1 \mathrm{~N} \mathrm{H}_{2} \mathrm{SO}_{4}$ or $1 \mathrm{~N} \mathrm{NaOH}$. After 1 week, in order to adapt the 
hydroponic culture system, the $\mathrm{H}_{2} \mathrm{O}$ was replaced and the plants were grown in $1 / 8$ strength Hoagland's solution (Hoagland and Snyder, 1933) for 1 week, in 1/4 strength Hoagland's solution for 1 week, and then in half-strength Hoagland's solution until the start of the treatment. After 1 week in half-strength solution, plants were transferred to the treatment solutions; half-strength Hoagland's solution containing $0,0.25,0.5$, $1.0,2.5$, or $5.0 \mathrm{mM} \mathrm{Al}$ as $\mathrm{Al}_{2}\left(\mathrm{SO}_{4}\right)_{3} \cdot 14-18 \mathrm{H}_{2} \mathrm{O}$. The $\mathrm{pH}$ was adjusted to 4.0 with $1 \mathrm{~N} \mathrm{H}_{2} \mathrm{SO}_{4}$. At the start of the treatments, the fresh weight of E. camaldulensis was $20 \pm 2 \mathrm{~g}$ plant -1 . The treatment solutions were renewed every week and continuously aerated. The $\mathrm{pH}$ of the treatment solution was adjusted every day during the treatment. Each experiment was carried out in triplicate. After 5 weeks from the start of treatment, three rooted cuttings from each treatment were immersed in dilute $\mathrm{H}_{2} \mathrm{SO}_{4}$ solution $(\mathrm{pH} 3)$ for 3 min to remove $\mathrm{Al}^{3+}$ compounds from the root surface, and then washed with deionized $\mathrm{H}_{2} \mathrm{O}$. After wiping with a paper towel, the plants were separated into leaves, stems, and roots, and each part was weighed. Then, leaves and roots were separated into young parts (which developed after the start of Al treatment) and mature parts. Young root samples were immediately stored at $-80{ }^{\circ} \mathrm{C}$ until analyses of organic acid contents and enzyme activities. At the same time, samples of young roots treated with $1.0 \mathrm{mM} \mathrm{Al}$ were cut with scissors, and root tips $(0-5 \mathrm{~mm})$ were used for ${ }^{27} \mathrm{Al}-\mathrm{NMR}$ analysis. The rest of the young roots and mature and young leaves were freeze-dried and ground into a fine powder to measure Al contents.

\subsection{Measurement of Al content}

Aliquots of powdered plant samples (approx. $50 \mathrm{mg}$ ) were digested with condensed $\mathrm{HNO}_{3}: \mathrm{HClO}_{4}(1: 1$ $\mathrm{v} / \mathrm{v}$ ) and completed to $25 \mathrm{ml}$ in a volumetric flask. This solution was used to measure $\mathrm{Al}$ using an atomic absorption spectrometer with a graphite furnace (Spectra AA with Zeeman correction, Varian, Australia).

\subsection{Measurement of organic acid contents}

Frozen young root samples (approx. $1.5 \mathrm{~g}$ ) were macerated with $3 \mathrm{M} \mathrm{HClO}_{4}(7.5 \mathrm{ml})$ and $1 \mathrm{mM}$ EDTA.2Na $(3 \mathrm{ml})$ with a cold mortar and pestle. After centrifugation at $5000 \mathrm{~g}$ for $10 \mathrm{~min}$ at $4{ }^{\circ} \mathrm{C}$, the supernatant was adjusted to $\mathrm{pH} 5.0$ with $0.5 \mathrm{~N} \mathrm{KOH}$ and kept on ice for $30 \mathrm{~min}$ before filtering through filter paper (No. 6, Advantec, Tokyo, Japan). The filtrate was used to analyze the contents of malate and citrate using enzymatic methods (Mollering, 1985). Water-soluble oxalate in frozen samples was extracted with deionized $\mathrm{H}_{2} \mathrm{O}$ for $1 \mathrm{~h}$. After filtering the solution, oxalate was analyzed using an ion-chromatograph (IC 500S, Yokogawa-Hokushin Electric, Tokyo, Japan) equipped with a guard column (IonPac AG4A-SC, $4 \times 50 \mathrm{~mm}$, Dionex, Sunnyvale, CA, USA) and an analytical column (IonPac AS4-SC, $4 \times 250 \mathrm{~mm}$, Dionex).

\subsection{Measurement of enzyme activities}

Young roots stored at $-80^{\circ} \mathrm{C}$ were homogenized with a mortar and pestle in cold $100 \mathrm{mM}$ HEPES-KOH buffer ( $\mathrm{pH}$ 8.0) containing $30 \mathrm{mM}$ sorbitol, $1 \%(\mathrm{v} / \mathrm{v})$ bovine serum albumin (BSA) and $5 \%(\mathrm{v} / \mathrm{v})$ polyvinylpolypyrrolidone. The homogenate was filtered through nylon mesh (120 mesh) and centrifuged at 10,000g for $15 \mathrm{~min}$, with the supernatant then used for enzyme assays. Activities of PEPC, MDH, CS, and 
NADP $^{+}$-ICDH were measured according to the method of López-Millán et al. (2000). The activity of ACO was measured by the method of Cooper and Beevers (1969). Briefly, the activities of PEPC and MDH were assayed spectrophotometrically by monitoring disappearance of NADH at $340 \mathrm{~nm}$. CS activity was assayed spectrophotometrically by following reduction of acetyl coenzyme A with 5,5'-dithio-bis-2-nitro benzoic acid at $412 \mathrm{~nm}$ for $3 \mathrm{~min}$. NADP ${ }^{+}$-ICDH activity was assayed spectrophotometrically by monitoring disappearance of NADPH at $340 \mathrm{~nm}$. ACO activity was measured spectrophotometrically by monitoring reduction of NADPH at $340 \mathrm{~nm}$.

\section{5. ${ }^{27} \mathrm{Al}$-nuclear magnetic resonance (NMR) analysis}

Cell sap was extracted from root tips (0-5 mm) according to the method of Ma et al. (1997b) and collected into an NMR tube (5 mm diameter). ${ }^{27} \mathrm{Al}-\mathrm{NMR}$ spectra were obtained at $156.3 \mathrm{MHz}$ (JNM- $\alpha 600$ spectrometer, JEOL, Tokyo, Japan) according to Morita et al. (2008). $\mathrm{AlCl}_{3}(0.2 \mathrm{mM}$ in $0.1 \mathrm{~N} \mathrm{HCl})$ was used as an external reference to calibrate the chemical shift $(0 \mathrm{ppm})$. The ${ }^{27} \mathrm{Al}-\mathrm{NMR}$ spectrum of the $\mathrm{Al}$-citrate, $\mathrm{Al}$-malate, and $\mathrm{Al}$-oxalate complexes, prepared by mixing $\mathrm{AlCl}_{3}$ with citric acid (1:1), malic acid (1:1), and oxalate (1:1), respectively, were recorded for comparison. The $\mathrm{pH}$ of the mixture was adjusted to that of the cell sap ( $\mathrm{pH} 4.3 \pm 0.2)$ with $0.1 \mathrm{~N} \mathrm{HCl}$. In addition, the contents of Al, malate, citrate, and oxalate in root cell sap were determined in young root samples as described above.

\subsection{Statistic analysis}

Data were analyzed statistically using Tukey test to determine significant difference in the data among the groups. $P$ values less than 0.05 were considered significant. The values are represented as mean $\pm \mathrm{S}$. D.

\section{Acknowledgments}

We thank Dr. Takayuki Asada at the Forestry Research Institute, OJI Paper Co., Ltd., Tokyo, Japan, for providing Eucalyptus plant materials.

\section{References}

Anoop, V.M., Basu, U., McCammon, M.T., McAlister, H.L., Taylor, G.J., 2003. Modulation of citrate metabolism alters aluminum tolerance in yeast and transgenic canola overexpressing a mitochondrial citrate synthase. Plant Physiol. 132, 2205-2217.

Cooper, G., Beevers, H., 1969. Mitochondria and glyoxysomes from castor bean endosperm. J. Biol. Chem. 244, 3507-3513.

Degenhardt, J., Larsen, P.B., Howell, S.H., Kochian, L.V., 1998. Aluminum resistance in the arabidopsis mutant alr-104 is caused by an aluminum-induced increase in rhizosphere pH. Plant Physiol. 117, 19-27.

Delhaize, E., Ryan, P.R., Randall, P.R., 1993. Aluminum tolerance in wheat (Triticum aestivum L.) II. Aluminum-stimulated excretion of malic acid from roots apices. Plant Physiol. 103, 695-702. 
Hiradate, S., 2004. Speciation of aluminum in soil environments. Soil Sci. Plant Nutr. 50, 303-314.

Hoagland, D.R., Snyder, W.C., 1933. Nutrition of strawberry plant under controlled conditions: (a) effects of deficiencies of boron and certain other elements: (b) susceptibility to injury from sodium salts. Proc. Amer. Soc. Hort. Sci. 30, 288-294.

Kania, A., Langlade, N., Martinoia, E., Neumann, G., 2003. Phosphorus deficiency-induced modifications in citrate catabolism and in cytosolic $\mathrm{pH}$ as related to citrate exudation in cluster roots of white lupin. Plant Soil 248, 117-127.

Kerven, G.L., Larsen, P.L., Bell, L.C., Edwards, D.G., 1995. Quantitative ${ }^{27}$ Al NMR spectroscopic studies of $\mathrm{Al}$ ( ) complexes with organic acid ligand and their comparison with GEOCHEM predicted values. Plant Soil 171, 35-39.

Kihara, T., Ohno, T., Koyama, H., Sawafuji, T., Hara, T., 2003a. Characterization of NADP-isocitrate dehydrogenase expression in a carrot mutant cell line with enhanced citrate excretion. Plant Soil 248, $145-153$.

Kihara, T., Wada, T., Suzuki, Y., Hara, T., Koyama, H., 2003b. Alteration of citrate metabolism in cluster roots of white lupin. Plant Cell Physiol. 44, 901-908.

Kitagawa, T., Morishima, T., Tachibana, Y., Namai, H., Ohta, Y., 1986. Differential aluminum tolerance in wheat and secretion of organic acids. Soil Sci. Plant Nutr. 57, 352-358.

Kochian, L.V., 1995. Cellular mechanisms of aluminum toxicity and resistance in plants. Annu. Rev. Plant Physiol. Plant Mol. Biol. 46, 237-260.

Konishi, S., Miyamoto, S., Taki, T., 1985. Stimulatory effects of aluminum on tea plants grown under low and high phosphorus supply. Soil Sci. Plant Nutr. 31, 361-368.

Koyama, H., Okawara, R., Ojima, K., and Yamaya, T., 1988. Re-evaluation of characteristics of a carrot cell line previously selected as aluminum-tolerant cell line. Physiol. Plant. 74, 683-687.

Li, X.F., Ma, J.F., Matsumoto, H., 2000. Pattern of Al-induced secretion of organic acids differ between rye and wheat. Plant Physiol. 123, 1537-1543.

López-Millán, A.F., Morales, F., Andaluz, S., Gogorcena, Y., Abadía, A., Rivas, J.D.L., Abadía, J., 2000. Responses of sugar beet roots to iron deficiency. Changes in carbon assimilation and oxygen use. Plant Physiol. 124, 885-897.

Ma, J.F., Hiradate, S., Matsumoto, H., 1997a. Detoxifying aluminum with buckwheat. Nature 390, $569-570$

Ma, J.F., Hiradate, S., Nomoto, K., Iwashita, T., Matsumoto, H., 1997b. Internal detoxification mechanism of $\mathrm{Al}$ in Hydrangea. Identification of $\mathrm{Al}$ form in the leaves. Plant Physiol. 113, 1033-1039.

Ma, J.F., Hiradate, S., Matsumoto, H., 1998. High aluminum resistance in buckwheat. II. Oxalic acid detoxifies aluminum internally. Plant Physiol. 117, 753-759.

Ma, J.F., Hiradate, S., 2000. Form of aluminum for uptake and translocation in buckwheat. Planta 211, 355-360.

Magalhaes, J.V., Liu, J., Guimarães, C.T., Lana, U.G.P., Alves, V.M.C., Wang, Y.H., Schaffert, R.E., Hoekenga, O.A., Piñeros, M.A., Shaff, J.E., Klein, P.E., Coelho, C.M., Kochian, L.V., 2007. A gene in 
the multidrug and toxic compound extrusion (MATE) family confers aluminum tolerance in sorghum. Nat Genet 39, 1156-1161.

Massonneau, A.S., Langlade, N., Leon, S., Smutny, J., Vogt, E., Neumann, G., Martinoia, E., 2001. Metabolic changes associated with cluster root development in white lupin (Lupinus albus L.): relationship between organic acid excretion, sucrose metabolism and energy status. Planta 213, 534-542.

Matsumoto, H., Hirasawa, E., Morimura, S., Takahashi, E., 1976. Localization of aluminum in tea leaves. Plant Cell Physiol. 17, 627-631.

Matsumoto, H., 2000. Cell biology of aluminum toxicity and tolerance in higher plants. Int. Rev. Cytol. 200, $1-46$.

Mollering, H., 1985. Method of Enzymatic Analysis, 3rd edition. Bergmeyer, H.U. (Ed), Verlag Chemie, Weinheim, pp. 2-12 and pp. 39-47.

Morita, A., Horie, H., Fujii, Y., Takatsu, S., Watanabe, N., Yagi, A., Yokota, H., 2004. Chemical forms of aluminum in xylem sap of tea plants (Camellia sinensis L.). Phytochemistry 65, 2775-2780.

Morita, A., Yanagisawa, O., Maeda, S., Hiradate, S., 2008. Mechanism for the detoxification of aluminum in roots of tea plant (Camellia sinensis L. Kuntze). Phytochemistry 69, 147-153.

Morita, A., Yanagisawa, O., Maeda, S., Takatsu, S., Ikka, T., 2011. Tea plant (Camellia sinensis L.) roots secrete oxalic acid along with caffeine, in response to aluminum. Soil Sci. Plant Nutr. 57, 796-802.

Mugai, E.N., Agong, S.G., Matsumoto, H. 2000. Aluminium tolerance mechanisms in Phaseolus vulgaris L.: citrate synthase activity and TTC reduction are well correlated with citrate secretion. Soil Sci. Plant Nutr. 46, 939-950.

Mullette, K.J., 1973. Stimulation of growth in Eucalyptus due to aluminum. Plant Soil 42, 495-499.

Mullette, K.J., Hannon, N.J., Elliott, A.G.L., 1974. Insoluble phosphorus usage by Eucalyptus. Plant Soil 41, 199-205.

Nagata, T., Hayatsu, M., Kosuge, N., 1992. Identification of aluminum forms in tea leaves by ${ }^{27}$ A1 NMR. Phytochemistry 31, 1215-1218.

Neumann, G., Martinoia, E., 2002. Cluster roots - an underground adaptation for survival in extreme environments. Trends Plant Sci. 7, 162-167.

Nguyen, N.T., Mohopatra, P.K., Fujita, K., 2003a. Leaf necrosis is a visual symptom of the shift from growth stimulation to inhibition effect of Al in Eucalyptus camaldulensis. Plant Sci. 165, 147-157.

Nguyen, N.T., Nakabayashi, K., Thompson, J., Fujita, K., 2003b. Role of exudation of organic acids and phosphate in aluminum tolerance of four tropical woody species. Tree Physiol. 23, 1041-1050.

Osaki, M., Watanabe, T., Tadano, T., 1997. Beneficial effects of aluminum on growth of plants adapted to low pH soils. Soil Sci. Plant Nutr. 43, 551-563.

Osaki, M., Watanabe, T., Ishizawa, T., Nilnond, C., Nuyim, T., Sittibush, C., Tadano, T., 1998. Nutritional characteristics in leaves of native plants grown in acid sulfate, peat, sandy podzolic, and saline soils distributed in Peninsular Thailand. Plant Soil 201, 175-182.

Pellet, D.M., Grunes, D.L., Kochian, L.V., 1995. Organic acid exudation as an aluminum-tolerance 
mechanism in maize (Zea mays). Planta 196, 788-795.

Rangel, A.F., Rao, I.M., Braun, H.P., Horst. W.J., 2010. Aluminum resistance in common bean (Phaseolus vulgaris) involves induction and maintenance of citrate exudation from root apices. Physiol. Plant. 138, 176-190.

Ryan, P.R., Delhaize, E., 2001. Function and mechanism of organic anion exudation from plant roots. Annu. Rev. Plant Physiol. Plant Mol. Biol. 52, 527-560.

Sadka, A., Dahan, E., Cohen, L., Marsh, K.B., 2000. Aconitase activity and expression during the development of lemon fruit. Physiol. Plant. 108, 255-262.

Sasaki, T., Yamamoto, Y., Ezaki, B., Katsuhara, M., Ahn, S.J., Ryan, P.R., Delhaize, E., Matsumoto, H., 2004. A wheat gene encoding an aluminum-activated malate transporter. Plant J. 37, 645-653.

Silva, J.R., Novais, R.F., Jham, G.N., Barros, N.F., Gebrim, F.O., Nunes, F.N., Neves, J.C.L., Leite, F.P., 2004. Responses of eucalypt species to aluminum: the possible involvement of low molecular weight organic acids in the $\mathrm{Al}$ tolerance mechanism. Tree Physiol. 24, 1267-1277.

Symonds, W.L., Campbell, L.C., Clemens, J., 2001. Response of ornamental Eucalyptus from acidic and alkaline habitats to potting medium $\mathrm{pH}$. Scientia Hort. 88, 121-131.

Tahara, K., Norisada, M., Hogetsu, T., Kojima, K., 2005. Aluminum tolerance and aluminum-induced deposition of callose and lignin in the root tips of Melaleuca and Eucalyptus species. J. For. Res. 10, 325-333.

Tahara, K., Norisada, M., Yamanoshita, T., Kojima, K., 2008. Role of aluminum-binding ligands in aluminum resistance of Eucalyptus camaldulensis and Melaleuca cajuputi. Plant Soil 302, 175-187.

Takita, E., Koyama, H., Hara, T., 1999. Organic acid metabolism in aluminum-phosphate utilizing cells of carrot (Daucus carota L.). Plant Cell Physiol. 40, 489-495.

Taylor, G.J., 1991. Current views of the aluminum stress response: the physiological basis of tolerance. Curr. Top Plant Biochem. Physiol. 10, 57-93.

van Breemen, N., Pons, L.J., 1978. Acid sulfate soils and rice. In Soils and Rice. (Ed), International Rice Research Institute. Los Baños, pp. 739-761.

Yang, Z.M., Nian, H., Sivaguru, M., Tanakamaru, S., Matsumoto, H., 2001. Characterization of aluminium-induced citrate secretion in aluminium-tolerant soybean (Glycine max) plants. Physiol. Plant. $113,64-71$.

Yang, Z.M., Yang, H., Wang, J., Wang, Y.S., 2004. Aluminum regulation of citrate metabolism for Al-induced citrate efflux in the roots of Cassia tora L. Plant Sci. 166, 1589-1594.

Zheng, S.J., Ma, J.F., Matsumoto, H., 1998. Continuous secretion of organic acids is related to aluminum resistance during relatively long-term exposure to aluminum stress. Physiol. Plant. 103, 209-214. 


\section{Figure}

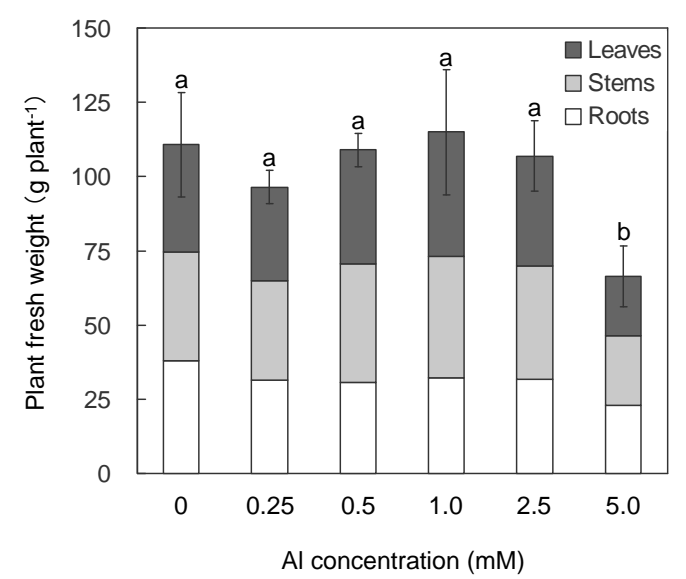

Fig. 1 Effect of Al on growth of Eucalyptus camaldulensis. Values are mean $\pm \mathrm{SD}(n=3)$. Means followed by different letters are significantly different at $P<0.05$.

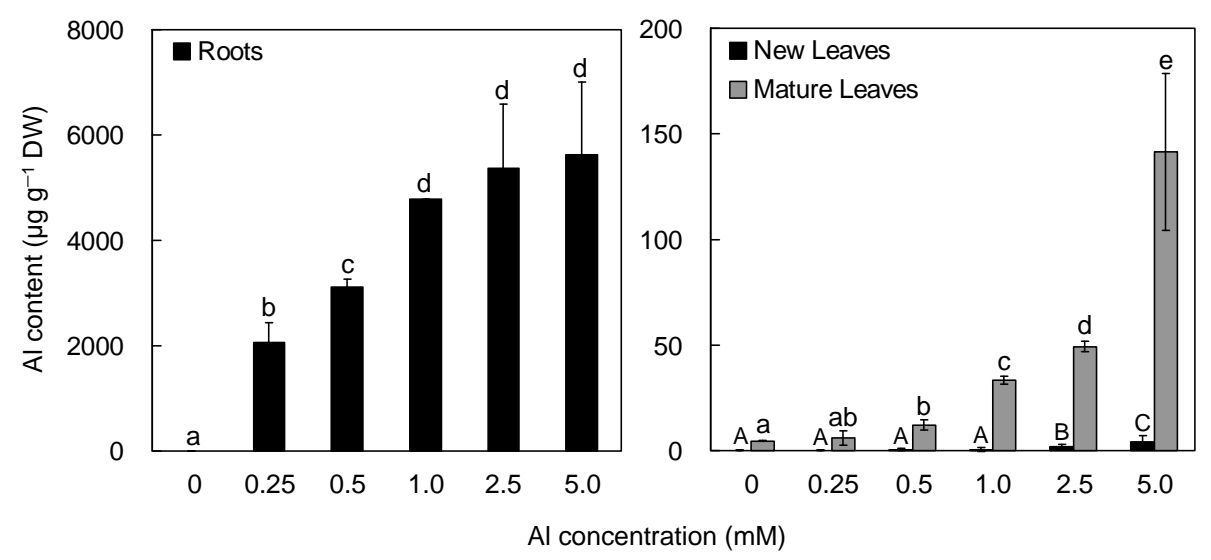

Fig. 2 Effect of Al on Al content in young and old leaves and young roots of Eucalyptus camaldulensis. Values are mean $\pm \operatorname{SD}(n=3)$. Means followed by different letters are significantly different at $P<0.05$. 

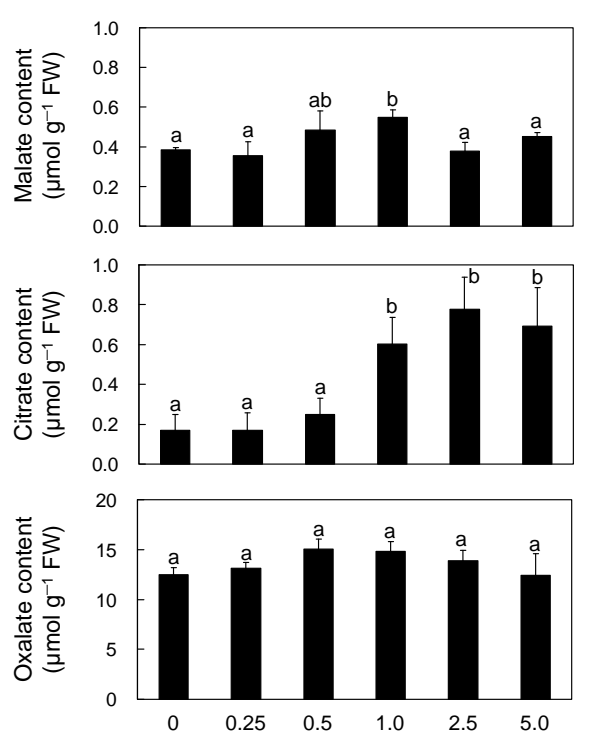

Al concentration ( $\mathrm{mM})$

Fig. 3 Effect of Al concentration on contents of malate, citrate and oxalate in young roots of Eucalyptus camaldulensis. Values are mean $\pm \operatorname{SD}(n=3)$. Means followed by different letters are significantly different at $P<0.05$.

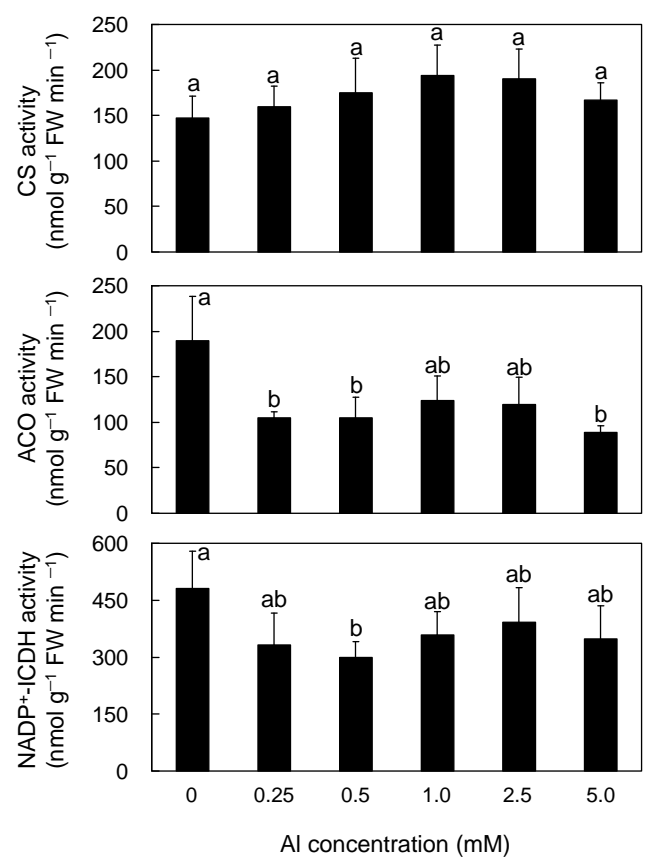

Fig. 5 Effect of Al concentration on activities of citrate synthase (CS), aconitase (ACO), and NADP+-isocitrate dehydrogenase (NADP+-ICDH) in young roots of

Eucalyptus camaldulensis. Values are mean $\pm \operatorname{SD}(n=3)$. Means followed by different letters are significantly different at $P<0.05$.
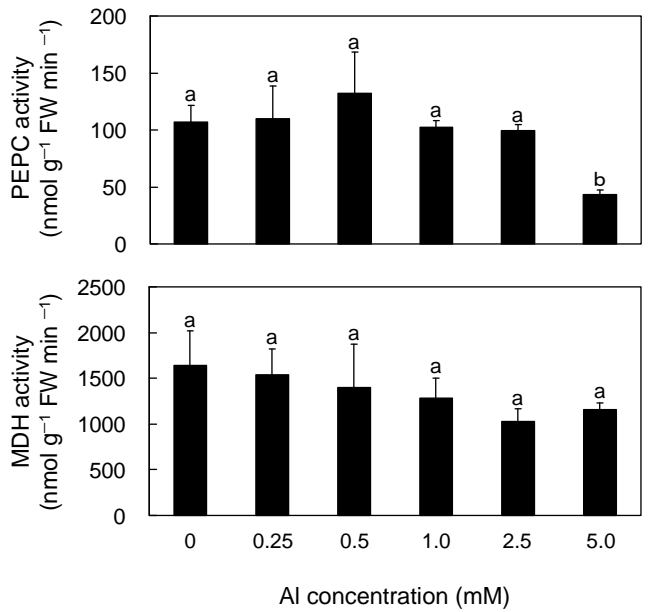

Fig. 4 Effect of Al concentration on activities of phosphoenolpyruvate carboxylase (PEPC) and malate dehydrogenase (MDH) in young roots of Eucalyptus camaldulensis. Values are mean $\pm \mathrm{SD}(n=3)$. Means followed by different letters are significantly different at $P<0.05$.

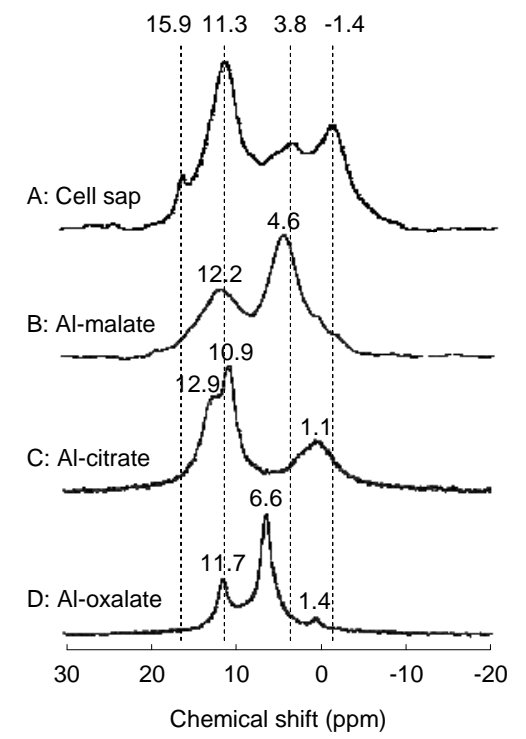

Fig. $6{ }^{27} \mathrm{Al}-\mathrm{NM}$ Spectrum of cell sap from root tips (A) of Eucalyptus camaldulensis grown in nutrient solution containing $\mathrm{Al} 1.0 \mathrm{mM}$ for 5 weeks and $\mathrm{Al}$ model solutions ( $\mathrm{pH} 4.3 \pm 0.2)$; Al-malate (B), Alcitrate (C), and Al-oxalate (D) solutions. Numerical values show chemical shifts (ppm) referenced to $\mathrm{AlCl}_{3}(0 \mathrm{ppm})$ 
Table $1 \mathrm{pH}$ values and contents of $\mathrm{Al}$ and organic acids in cell sap of root tips treated with $1.0 \mathrm{mM} \mathrm{Al}$.

\begin{tabular}{ll}
\hline Measurement & Value \\
\hline $\mathrm{pH}$ & 4.32 \\
$\mathrm{Al}(\mathrm{mM})$ & 1.032 \\
Malate $(\mathrm{mM})$ & 1.489 \\
Citrate $(\mathrm{mM})$ & 1.300 \\
Oxalate $(\mathrm{mM})$ & 0.258 \\
\hline
\end{tabular}

